\title{
Penentuan Ketidakpastian Pengukuran Kadar Kafein pada Biji Kakao (Theobroma Cacao L.) Menggunakan Spektrofotometri UV-Vis
}

\author{
Devita Wijiyanti dan Thorikul Huda \\ Jurusan Kimia, FMIPA \\ Universitas Islam Indonesia Yogyakarta \\ Devita_Wijiyanti@yahoo.com
}

\begin{abstract}
Abstrak
Telah dilakukan penelitian penentuan ketidakpastian pengukuran kadar kafein pada biji kakao dengan metode spektrofotometer UV-Vis. Tujuan penelitian adalah penentuan ketidakpastian pengukuran kadar kafein pada biji kakao. Kafein pada ekstrak biji kakao dianalisis menggunakan spektrofotometer UV-Vis pada panjang gelombnag $273 \mathrm{~nm}$, diperoleh persamaan regresi linear $\mathrm{y}=0,0497 \mathrm{x}+0,0028$ dengan koefisien determinan $\mathrm{R}^{2}$ 0,9996. Hasil penelitian menunjukkan bahwa kadar kafein sebesar 26,40 mg/g. Nilai LOD dan LOQ sebesar 0,52 mg/L dan 1,73 mg/L. Faktor penyumbang ketidakpastian adalah konsentrasi (c), massa (m), faktor pengenceran dan presisi dengan estimasi ketidakpastian pengukuran sebesar 3,11 mg/g. Hasil pengujian dapat dilaporakan dengan nilai $26,40 \pm 3,11 \mathrm{mg} / \mathrm{g}$.
\end{abstract}

Kata-kata kunci: biji kakao (Theobroma cacao L.), kefein, ketidakpastian pengukuran, spektrofotometer UV-Vis

\begin{abstract}
A study on the determination of uncertainty in measurement of caffeine content in cocoa beans by UV-Vis spectrophotometer method. The aim of this study was to determine the uncertainty of measurement of caffeine content in cocoa beans. Caffeine in cocoa bean extract was analyzed using UV-Vis spectrophotometer at 273 $n m$ wavelength, obtained by linear regression equation $y=0,0497 x+0,0028$ with determinant coefficient $R^{2}$ 0,9996. The results showed that caffeine content of $26.40 \mathrm{mg} / \mathrm{g}$. LOD and LOQ values were $0.52 \mathrm{mg} / \mathrm{L}$ and $1.73 \mathrm{mg} / \mathrm{L}$. The contributing factors of uncertainty are concentration $(\mathrm{c})$, mass $(\mathrm{m})$, dilution factor and precision with an estimated uncertainty of measurement of $3.11 \mathrm{mg} / \mathrm{g}$. Test results can be reported with a value of $26.40 \pm 3.11 \mathrm{mg} / \mathrm{g}$.
\end{abstract}

Keywords: cocoa beans (Theobroma cacao L.), caffeine, uncertainty measurement, UV-Vis spectrophotometer

\section{PENDAHULUAN}

Kafein ialah senyawa alkaloid xantina berbentuk kristal dan berasa pahit yang bekerja sebagai obat perangsang psikoaktif dan diuretik ringan (Maramis, 2013). Kafein merupakan senyawa kimia alkaloid yang terkandung secara alami pada lebih dari 60 jenis tanaman. Kafein diproduksi secara komersial dengan cara ekstraksi dari tanaman tertentu serta diproduksi secara sintetis. Kebanyakan produksi kafein bertujuan untuk memenuhi kebutuhan industri minuman. Kafein juga digunakan sebagai penguat rasa atau bumbu pada berbagai industri makanan (Paradkar, dkk., 2002). Berdasarkan FDA (Food Drug Administration), dosis kafein yang diizinkan $100-$ $200 \mathrm{mg} /$ hari, sedangkan menurut SNI 01- 71522006 batas maksimum kafein dalam makanan dan minuman adalah $150 \mathrm{mg} / \mathrm{hari}$ dan $50 \mathrm{mg} / \mathrm{sajian}$. Kafein adalah salah satu jenis alkaloid yang banyak terdapat dalam biji kopi, daun teh, dan biji coklat (Maramis, 2013).

Spektrofotometri merupakan salah satu metode dalam kimia analisis yang digunakan untuk menentukan komposisi suatu sampel baik secara kuantitatif dan kualitatif yang didasarkan pada interaksi antara materi dengan cahaya. Peralatan yang digunakan dalam spektrofotometri disebut spektrofotometer. Cahaya yang dimaksud dapat berupa cahaya visibel, UV dan inframerah, sedangkan materi dapat berupa atom dan molekul namun yang lebih berperan adalah elektron valensi. Metode spektrofotometri UV-Vis memiliki kelebihan antara lain analisis lebih sederhana, cepat, ekonomis, dan sensitif dibandingkan dengan metode secara KCKT memerlukan instrumentasi yang relative mahal dan rumit (Suryadi, dkk., 2014). 
Ketidakpastian pengukuran adalah suatu parameter yang menetapkan rentang nilai yang didalamnya diperkirakan nilai benarnya. Ketidakpastian pengukuran perlu dilakukan karena saat melakukan pengukuran menggunakan instrumentasi tidak mungkin mendapatkan nilai yang pasti benar melainkan adanya faktor yang dapat menyebabkan nilai tidak pasti dari hasil pengukuran. Sumber-sumber ketidakpastian dalam pengukuran yaitu sampling, preparasi contoh, kalibrasi peralatan instrumen, kesalahan random kesalahan dan sistematik personil (Kartasubrata, dkk., 2003).

\section{METODE}

Penelitian yang dilakukan diawali dengan menentukan panjang gelombang kafein dan menentukan kurva kalibrasi. Sampel yang digunakan pada penelitian ini yaitu biji kakao. Tahapan penelitian ini yaitu biji kakao diblender dilarutkan kedalam air panas sebanyak $30 \mathrm{~mL}$, kemudian disaring dan diekstraksi dengan menggunakan pelarut kloroform sebanyak $15 \mathrm{~mL}$ dan amonia 37\% sebanyak $5 \mathrm{~mL}$. Ekstraksi dilakukan sebanyak tiga kali, hasil ekstraksi ditampung dalam wadah, kemudian ekstrak yang diperolah diuapkan didalam evaporator. Hasil ekstrak kental dari evaporator di analisis dengan menggunakan instrumen spektrofotometer UV-Vis Double Beam untuk ditentukan kadar kafeinnya.

\section{HASIL DAN PEMBAHASAN}

Penentuan ketidakpastian pengukuran kadar kafein pada biji kakao (Theobroma cacao L.) menggunakan spektrofotometer UV-Vis Double Beam diawali dengan melarutkan bubuk kakao menggunakan air panas dan kemudian diekstraksi dengan menggunakan pelarut kloroform dan amonia 37\%. Pelarutan kakao dengan menggunakan air panas dimaksudkan karena didalam biji kakao terdapat kandungan bahan kimia aroma, warna dan ampas yang hanya dapat larut dengan menggunakan air panas. Air panas berfungsi untuk memisahkan ampas dari bahan kimia. Penentuan ketidakpastian pengukuran memiliki beberapa parameter pengujian

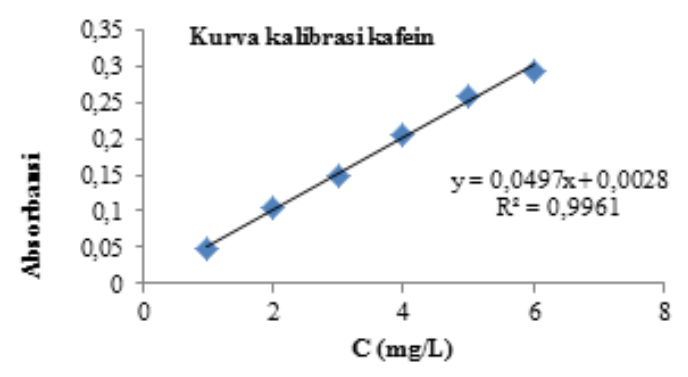

Gambar 1. Kurva Kalibrasi yang harus dilakukan dan parameter yang harus dipenuhi yaitu linearitas, LOD dan LOQ, presisi, dan akurasi. Linieritas merupakan persamaan kurva kalibrasi yang menunjukkan hubungan antara konsentrasi larutan standar kafein dengan respon absorbansi pada pengujian menggunakan spektrofotometer UV-Vis. Larutan standart kafein dibuat dengan variasi konsentrasi 1 sampai dengan 6 mg/L. Menurut Chan, dkk., (2004) persamaan kurva kalibrasi bisa dikatakan linier apabila nilai koefesien determinasi memenuhi syarat keberterimaan $\left(\mathrm{r}^{2}\right)>$ 0,9970 (Riyanto, 2014). Berdasarkan grafik gambar 1 penentuan kadar kefein dalam kakao didapatkan nilai koefesien determinasi $\left(\mathrm{r}^{2}\right)$ sebesar 0,9961 .

LOD adalah konsentrasi analit terkecil yang masih dapat dideteksi, namun tidak perlu ditentukan kuantitasnya. LOQ adalah kadar analit terendah yang bisa diukur dengan menggunakan presisi dan akurasi, sesuai kondisi prosedur yang telah disepakati. Penentuan limit deteksi memiliki cara berbeda-beda tergantung metode yang digunakan menggunakan instrument atau tidak (Riyanto, 2014). Pada metode kurva kalibrasi ini LOD dan LOQ merupakan nilai konsentrasi terkecil analit yang dapat diukur oleh instrument. Nilai LOD dan LOQ yang didapat dari kurva kalibrasi masing-masing adalah $0,52 \mathrm{mg} / \mathrm{L}$ dan $1,73 \mathrm{mg} / \mathrm{L}$. Presisi adalah nilai yang menunjukkan kedekatan antara uji satu dengan uji lainnya dalam satu rangkaian pengujian. Preisi dikelompokkan menjadi dua yaitu repitibilitas dan reprodusibiltas. Repitibilitas digunakan apabila suatu penelitian tersebut dilakukan oleh analis, metode dan alat yang sama dengan rentang waktu yang pendek. Sedangkan reprodusibilitas digunakan apabila penelitian dilakukan oleh metode dan alat yang sama namun dengan personel/analis yang berbeda. Kriteria umum keberterimaan nilai presisi sesuai persyaratan yaitu nilai $\%$ RSD $\leq 5-10 \%$. Namun kriteria ini fleksibel tergantung konsentrasi analit yang dianalisis, jumlah sampel dan kondisi laboratorium. Hasil uji presisi pada penentuan ketidakpastian kadar kafein dalam biji kakao ini adalah sebesar 3,05\%. Nilai ini bisa dikatakan baik karena memiliki nilai $\%$ RPD $\leq 5-10 \%$.

Tabel 1. Hasil Uji Presisi Penentuan Kadar Kafein Pada Kakao

\begin{tabular}{c|c}
\hline No & Konsentrasi (mg/L) \\
\hline 1 & 2,6800 \\
2 & 2,5995 \\
Rata-rata & 2,6397 \\
\%RPD & $3,05 \%$ \\
\hline
\end{tabular}

Tabel 2. Hasil Uji Akurasi

\begin{tabular}{lcl}
\hline Data & Rata-rata Absorbansi & Konsentrasi (mg/L) \\
\hline Spike & 1,1835 & 23,7565 \\
Contoh & 0,134 & 2,6397 \\
\hline
\end{tabular}


Akurasi adalah ukuran yang menunjukkan nilai kedekatan hasil uji dengan kadar sebenarnya. Akurasi dapat ditentukan melalui dua cara, yaitu metode simulasi dan metode penambahan. Metode yang digunakan dalam penelitian ini adalah metode simulasi yaitu dengan menambahkan larutan standar ke dalam sampel dengan konsentrasi tertentu atau biasa disebut larutan spike. Konsentrasi yang ditambahkan adalah $100 \mathrm{mg} / \mathrm{L}$ sebanyak $1 \mathrm{~mL}$.

Hasil uji akurasi penentuan kadar kafein dalam biji kakao yaitu sebesar $84,46 \%$. Nilai recovery yang diterima pada konsentrasi ppm yaitu $80-110 \%$. Faktor penyumbang ketidakpastian pada pengujian kafein dalam biji kakao adalah konsentrasi dari kurva kalibrasi (c), massa contoh (m), faktor pengenceran dan presisi hasil pengujian estimasi ketidakpastian diperoleh nilai sebesar $3,11 \mathrm{mg} / \mathrm{L}$ sehingga hasil

\section{DAFTAR PUSTAKA}

Chan, C.C., Lee, Y.C., Lam, H. and Zhang, X.M.eds., 2004. Analytical method validation and instrument performance verification. John Wiley \& Sons.

Kantasubrata, J. 2003. Dasar Ketidakpastian Pengukuran. Pengantar ISO Guide Uncertainty of Measurement, Serpong, 22-23.

Maramis, R. K. 2013. Analisis kafein dalam kopi bubuk di Kota Manado menggunakan spektrofotometri UV VIS. Pharmacon, 2(4). penelitian ini dapat dilaporkan dengan nilai $26,40 \pm$ $3,11 \mathrm{mg} / \mathrm{L}$.

\section{KESIMPULAN}

Berdasarkan penelitian penentuan ketidakpastian pengukuran kadar kafein pada biji kakao (Theobroma Cacao L.) menggunakan spektrofotometer UV-Vis dapat disimpulkan nilai presisi yang diperoleh sebesar 3,05\% lebih kecil dari 5-10\%, akurasi sebesar $84,46 \%$, LOD dan LOQ masing-masing sebesar $0,52 \mathrm{mg} / \mathrm{L}$ dan 1,73 $\mathrm{mg} / \mathrm{L}$, nilai linearitas sebesar 0,9980 lebih besar dari 0,995 , kadar kafein pada biji kakao sebesar $26,40 \mathrm{mg} / \mathrm{g}$ serta faktor penyumbang ketidakpastian pengukuran sebesar $3,11 \mathrm{mg} / \mathrm{L}$. Oleh karena itu hasil penenlitian penentuan ketidakpastian pengukuran kadar kafein pada biji kakao (Theobroma Cacao L.) ini dapat dilaporkan dengan nilai $26,40 \mathrm{mg} / \mathrm{g} \pm 3,11 \mathrm{mg} / \mathrm{L}$.

Paradkar, M. M., \& Irudayaraj, J. (2002). A rapid FTIR spectroscopic method for estimation of caffeine in soft drinks and total methylxanthines in tea and coffee. Journal of food science, 67(7), 2507-2511.

Riyanto. 2014. Validasi Dan Verifikasi Metode Uji Dolor, 31 .

Suryadi, H., \& Kurniadi, M. (2014). Analisis formalin dalam sampel ikan dan udang segar dari pasar muara angke. Pharmaceutical Sciences and Research (PSR), 7(3). 